\title{
ELDERLY SCREENING IN SONGGON BANYUWANGI 2019
}

Lukman Hakim ${ }^{1}$, Wildan Anugrah Erlangga ${ }^{1}$, Pandu Satriya Adi' ${ }^{1}$ Fitri Nurina Septiana $^{1}$, Emilia Eka Arianti ${ }^{1}$, Prafidina Qualisa ${ }^{1}$, Ariikah Dyah Lamara ${ }^{1}$, Estya Nadya Meitavany ${ }^{1}$, Niswah Silmi Fatimah ${ }^{1}$, Ulinnuha Qurrota $\mathbf{A}^{1}$, Sulistiawati ${ }^{2}$

${ }^{1}$ Medical Student, Faculty of Medicine, Universitas Airlangga, Surabaya, ${ }^{2}$ Department of Public HealthPreventive Medicine, Faculty of Medicine, Universitas Airlangga, Surabaya, Indonesia

\section{ABSTRACT}

Health care efforts for the elderly to keep the elderly healthy, independent, active and productive socially and economically, to realize this, the government is obliged to guarantee the availability of health service facilities and facilitate the development of the elderly group. The aim to identify factors that affect the achievement of health care coverage of the elderly. This was a qualitative descriptive study. This research was conducted in Songgon District. The target sample was the elderly residents and elderly Posyandu cadres. Data collection instruments using questionnaires. This study used primary data. Univariate analysis to determine the distribution using SPSS and Excel tools. $84 \%$ of elderly people knew about screening. The coverage of elderly screening was still low. From the results of research on community therapy that could be done was cadre training, reporting of the elderly, and Extension of Posyandu Elderly by Cadres for the Community.

\section{ARTICLE HISTORY}

Received: February 8, 2020

Revised: May 24, 2020

Accepted: June 9, 2020

Published: June 30, 2020

(Online)

doi: $10.20473 / \mathrm{jcmphr} . v 1 \mathrm{i} 1.20300$

\section{KEYWORDS}

Elderly, screening, posyandu

\section{CORRESPONDING AUTHOR}

Sulistiawati

\sulistiawati@fk.unair.ac.id Department of Public HealthPreventive Medicine, Faculty of Medicine, Universitas Airlangga, Jl. Meyjen Prof. Dr. Moestopo 47 Surabaya 60131 Indonesia

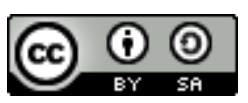

\section{INTRODUCTION}

Based on the Guidelines for Health Management in the Elderly Group, services in the elderly group include physical and mental health examinations. Kartu Menuju Sehat (KMS) for elderly as a recording and monitoring tool to find out early illnesses suffered (early detection) or threats to health problems faced and record progress in the Health Maintenance Guidelines (Buku Pedoman Pemeliharaan Kesehatan/BPPK) elderly or records of commonly used health conditions at the health center. ${ }^{1}$
The purpose of forming a posyandu for the elderly in general is to improve the health and quality of life of the elderly group to achieve a happy and efficient old age in the life of the family and community following their existence. Meanwhile, the specific objectives of the formation of the elderly posyandu are to: increase the awareness of the elderly to foster their health, increase the ability and participation of families and communities in overcoming elderly health, improve the type and reach of elderly health services, and to improve the quality of elderly health services. ${ }^{1}$ The targets of the Posyandu for the elderly are divided into two, namely: Direct targets which include 
pre elderly (45 - 59 years), elderly (60 - 69 years), and high risk elderly ( $>70$ years), and indirect targets, which include families elderly people, the community around the elderly, social organizations that care about the development of elderly health, elderly health workers, and the wider community. ${ }^{2}$

The elderly is someone who has reached the age of 60 years and over. The composition of the elderly population is growing rapidly in developed and developing countries. Globally, Asia and Indonesia from 2015 have entered the era of the aging population (aging population ) because the elderly population exceeds $7 \%$. The projection of the elderly population in Indonesia in 2017 is estimated at 23.66 million people $(9.03 \%)$. Then in 2020 , there will be 27.08 million people, in 2025 there will be 33.69 million people, in 2030 there will be 40.95 million people, until 2035 there will be 48.19 million people. This is certainly a problem in the health sector where one of the community groups most in need of health services in the elderly population. In 2015, the morbidity rate for the elderly was $28.6 \%$, where every 100 elderly people 28 of them were sick. ${ }^{3}$

In dealing with these problems, there are efforts to maintain health for the elderly to keep these elderly people healthy, independent, active and productive socially and economically, to realize this, the government is obliged to guarantee the availability of health service facilities and facilitate the development elderly group. In 2000, the Ministry of Health developed elderly polite health services that were held at the Puskesmas. This concept prioritizes efforts to foster health in an integrated, comprehensive, and sustainable manner in society. Susenas 2017 results show that there are 5 provinces with the percentage of elderly more than $10 \%$, namely DIY (13.9\%), Central Java $(12.46 \%)$, East Java (12.16\%), Bali $(10.79 \%)$, and West Sulawesi (10.37\%). ${ }^{4-6}$

The Songgon Community Health Center has an area of $301.84 \mathrm{~km}^{2}$. The working area of the Tegalsari puskesmas consists of 9 villages namely Songgon Village, Balak Village, Sragi Village, Parangharjo Village, Bedewang Village, Bayu Village, Sumberbulu Village, Sumberarum Village, Bangunsari Village. The total population in Songgon District is 50,499 with a total male population of 24,613 while the total female population is 25,886 . The Songgon health center also has an elderly health care program including posyandu for the elderly and posbindu PTM (noncommunicable diseases), the majority of patients are elderly with DM (diabetes mellitus) and hypertension. According to data from the Central Statistics Agency (BPS), the projected number of elderly people in Songgon District is 7,770 people.

Based on the 2018 Songgon Health Center PKP data, the target coverage for health services and screening at the elderly is $100 \%$ of the total projection of the elderly population. But in reality only $80.9 \%$ percent was achieved. This is certainly still far from the target of Puskesmas Songgon (2018). Based on monthly reports owned by the person in charge of elderly Songgon Health Center, up to April 2019, 2159 elderly people have been screened, and still leaves approximately 5611 elderly 
people who have not been screened. This shows that the coverage of elderly health screening up to April 2019 has only been reached by $27.8 \%$. While the target calculation if until April. should reach 2588 people. Then the target for 4 months has been fulfilled by $83 \%$ (Monthly Report on Songgon Community Health Center, 2019). Based on the data above, there needs to be an effort to find out the factors that cause the low achievement of the coverage of elderly health services .

\section{MATERIALS AND METHODS}

This type of research is a qualitative descriptive study. This study will examine cadre knowledge about posyandu, cadre knowledge about the coverage of the number of new elderly in posyandu and screening of the elderly, and cadre attitudes about coverage of the number of new elderly in posyandu and screening of the elderly. The population studied was elderly cadres of Bedewang village, Songgon District, Banyuwangi Regency. The sampling technique is done by incidental sampling. The target sample is the elderly residents and elderly Posyandu cadres of Bedewang Village on May 11, 2019 who are willing to become respondents. Calculations using the sample size formula without knowing the population size found that a minimum sample of research was 32 people and to anticipate the drop out a sample of 40 people was taken. The inclusion criteria in this study were elderly citizens and cadre mothers who were able to communicate actively well. The exclusion criteria in this study were residents who did not deign to become research subjects.

Data collection instruments using questionnaires that have been made and adjusted for the aim of research. The questionnaire is intended for the elderly to know gender, education, occupation, family members in the same household, knowledge about elderly screening, attitudes about elderly screening, family support, active posyandu cadres, elderly opinions about posyandu, distance/accessibility of the elderly to posyandu, and cadre knowledge Integrated Healthcare Center. The questionnaire was intended for cadres to know cadre knowledge about posyandu, cadre knowledge about the coverage of the number of new elderly in posyandu and screening of the elderly, and the attitude of cadres about coverage of the number of new elderly in posyandu and screening of the elderly.

The collection in this study is to use primary data, namely data taken directly by researchers with questionnaires to obtain information about cadre knowledge about posyandu, cadre knowledge about coverage of the number of new elderly people in posyandu and screening of the elderly, and the attitude of cadres about coverage of the number of new elderly at posyandu and screening of the elderly. The data obtained were performed univariate analysis to determine the distribution using SPSS and Excel tools. 


\section{RESULT}

Table 1. Results Analysis of Research Subjects in Bedewang Songgon Banyuwangi

\begin{tabular}{|c|c|c|c|}
\hline & & $\begin{array}{l}\text { Frequency } \\
\text { (n) }\end{array}$ & $\begin{array}{l}\text { Presentage } \\
\quad(\%)\end{array}$ \\
\hline \multirow[t]{2}{*}{ Knowledge of screening } & Yes & 4 & $16 \%$ \\
\hline & Not & 20 & $84 \%$ \\
\hline Elderly Opinions About the & Early detection & 17 & $69 \%$ \\
\hline \multirow[t]{2}{*}{ Purpose of Screening } & Treat & 4 & $19 \%$ \\
\hline & Detection and treat & 3 & $12 \%$ \\
\hline Elderly Opinions & Bloof Tension and Blood & 1 & $6 \%$ \\
\hline \multirow[t]{3}{*}{ About Screening Activities } & Sugar & & \\
\hline & Tension and Cholesterol & 1 & $6 \%$ \\
\hline & $\begin{array}{l}\text { Tension, blood sugar, } \\
\text { cholesterol, uric acid }\end{array}$ & 22 & $88 \%$ \\
\hline \multirow[t]{3}{*}{ Attitudes About Screening } & Less & 0 & $0 \%$ \\
\hline & Enough & 10 & $42 \%$ \\
\hline & Good & 14 & $58 \%$ \\
\hline Family Support of & Less & 1 & $5 \%$ \\
\hline \multirow[t]{2}{*}{ Respondents to Posyandu } & Enough & 18 & $74 \%$ \\
\hline & Good & 5 & $21 \%$ \\
\hline Posyandu Cadre Activities by & Less & 0 & $0 \%$ \\
\hline \multirow[t]{2}{*}{ Respondents } & Enough & 20 & $84 \%$ \\
\hline & Good & 4 & $16 \%$ \\
\hline Elderly Opinion About & Routine inspection & 11 & $45 \%$ \\
\hline \multirow{2}{*}{ Posyandu } & Improving the quality of health & 7 & $30 \%$ \\
\hline & Treatment when sick & 6 & $25 \%$ \\
\hline Ease of access to Posyandu / & Easy & 5 & $21 \%$ \\
\hline Accessibility & Not easy & 19 & $79 \%$ \\
\hline \multirow[t]{3}{*}{ Transportation to Posyandu } & Motorcycle & 6 & $26 \%$ \\
\hline & Pedaling bicycle & 3 & $11 \%$ \\
\hline & On foot & 15 & $63 \%$ \\
\hline \multirow{3}{*}{$\begin{array}{l}\text { Time Required for Elders to go } \\
\text { to Posyandu }\end{array}$} & 0 - 5 minutes & 22 & $88 \%$ \\
\hline & $6-10$ minutes & 1 & $6 \%$ \\
\hline & $11-15$ minutes & 1 & $6 \%$ \\
\hline Distance from Home to & $0-200 \mathrm{~m}$ & 11 & $45 \%$ \\
\hline \multirow[t]{4}{*}{ Posyandu } & $201-400 \mathrm{~m}$ & 9 & $35 \%$ \\
\hline & $401-600 m$ & 0 & $0 \%$ \\
\hline & $601-800 \mathrm{~m}$ & 2 & $10 \%$ \\
\hline & $800-1000 m$ & 2 & $10 \%$ \\
\hline Place of Health Check that is & Public health center & 10 & $40 \%$ \\
\hline $\begin{array}{l}\text { addressed by elderly who do } \\
\text { not come to Posyandu }\end{array}$ & $\begin{array}{l}\text { Independent practice of } \\
\text { midwives / nurses / doctors }\end{array}$ & 14 & $60 \%$ \\
\hline Reasons for the Elderly Not & Busy working & 5 & $20 \%$ \\
\hline \multirow[t]{3}{*}{ Coming to Posyandu } & There are no complaints & 9 & $40 \%$ \\
\hline & Difficulty reaching posyandu & 5 & $20 \%$ \\
\hline & $\begin{array}{l}\text { No complaints, difficulties } \\
\text { reaching the posyandu }\end{array}$ & 5 & $20 \%$ \\
\hline
\end{tabular}


Table 2. Distribution of Characteristics of Research Subjects in Bedewang Village, Songgon District, Banyuwangi Regency

\begin{tabular}{lcc}
\hline Characteristics & Frequency (n) & Persentage (\%) \\
\hline Gender & 8 & $33 \%$ \\
Male & 16 & $67 \%$ \\
Girl & & \\
Education & 4 & $16 \%$ \\
No school & 18 & $72 \%$ \\
Graduated from elementary school & 1 & $4 \%$ \\
Graduated Middle School & 1 & $4 \%$ \\
Graduated high school & 0 & $0 \%$ \\
Graduated from Higher Education & & \\
Profession & 7 & $28 \%$ \\
Houswife & 1 & $4 \%$ \\
Retired & 14 & $56 \%$ \\
Farmers & 2 & $8 \%$ \\
Does not work & & \\
Entire Family Members & 19 & $79.2 \%$ \\
Have any & 5 & $20.8 \%$ \\
Do not have & & \\
\hline
\end{tabular}

Table 3. Research Results with Cadres as Research Subjects

\begin{tabular}{|c|c|c|}
\hline & Frequency $(\mathrm{n})$ & Percentage $(\%)$ \\
\hline \multicolumn{3}{|l|}{ Proposal to Increase Coverage of New Elderly in Posyandu } \\
\hline Increase the number of posyandu & 1 & $25 \%$ \\
\hline Provide information to the public about posyandu & 4 & $100 \%$ \\
\hline Provide counseling about the importance of posyandu & 2 & $50 \%$ \\
\hline Increase the number of cadres & 0 & $0 \%$ \\
\hline Add infrastructure & 1 & $25 \%$ \\
\hline Etc & 0 & $0 \%$ \\
\hline \multicolumn{3}{|l|}{ A Solution A Cadre Can Do to Increase Coverage of New } \\
\hline Elderly in Elderly Posyandu & & \\
\hline Provide counseling about the importance of posyandu & 3 & $75 \%$ \\
\hline Come home and invite the elderly & 4 & $100 \%$ \\
\hline Call the elderly / family and invite & 1 & $25 \%$ \\
\hline Others & 0 & $0 \%$ \\
\hline \multicolumn{3}{|l|}{ Proposal to Increase Coverage of Elderly Screening } \\
\hline Providing information to the public about screening & 4 & $100 \%$ \\
\hline $\begin{array}{l}\text { Provide counseling about the importance of screening the } \\
\text { elderly }\end{array}$ & 4 & $100 \%$ \\
\hline Increase the number of cadres & 0 & $0 \%$ \\
\hline Providing facilities / infrastructure & 0 & $0 \%$ \\
\hline Others & 0 & $0 \%$ \\
\hline \multicolumn{3}{|l|}{$\begin{array}{l}\text { The Solution Can Be Done by Cadres to Increase the } \\
\text { Coverage of Elderly Screening }\end{array}$} \\
\hline Provide counseling about the importance of posyandu & 1 & $25 \%$ \\
\hline Come home and invite the elderly & 4 & $100 \%$ \\
\hline Call the elderly / family and invite & 1 & $25 \%$ \\
\hline Others & 0 & $0 \%$ \\
\hline
\end{tabular}


This research was conducted in Songgon District. Songgon District has an area of $301.84 \mathrm{~km} 2$, which is divided into 9 villages, with a total population of 50,499 residents consisting of 24,613 male residents and 25,886 female residents. Songgon is administratively located in Banyuwangi Regency. Relatively Songgon District has the following boundaries: north of Glagah and Kabat, west of Bondowoso, east of Singojuruh, and south of Sempu. The subjects of this study were the elderly in Bedewang Village with a total of 24 research subjects. Characteristics of research subjects are further described in the table below.

\section{DISCUSSION}

In this study it was found that the most recent education from respondents was elementary school graduates. Based on previous studies the level of education has no influence in increasing the elderly's visit to the posyandu. ${ }^{7}$ Data from the Central Statistics Agency in 2017 about the statistics of the elderly population. According to the data, there are still many elderly people living in rural areas who work and the majority work in the agricultural sector. $^{6}$ Other research states that family support for the elderly who are categorized better is more obtained than family support for the elderly who are categorized as less. Elderly support in the study may include the same place of residence. Elders understand that the purpose of screening is that screening is an early detection effort. The opinion of the elderly regarding the activities carried out during the most screening is the examination of blood pressure, blood sugar, cholesterol levels, and uric acid. While the other respondents know the activities carried out during screening are blood pressure checks, blood sugar levels, blood pressure checks and cholesterol levels.

Based on the results of the study, lsia did not know that in the elderly screening series MMSE screening and depression were performed in addition to checking blood pressure, blood sugar, blood cholesterol, and uric acid. This shows that the elderly do not yet know completely about elderly screening. As many as 58\% have good attitude and $42 \%$ have enough attitude about screening elderly. Based on research conducted by Idayani et al (2012) involving $\quad 70 \quad$ elderly respondents, it was concluded that there is a relationship between the knowledge and attitudes of the elderly with the activeness of the elderly towards the use of elderly Posyandu. ${ }^{8}$

The results of the study on 19 elderly respondents received sufficient family support. This is in line with research by Melita and Nadjib (2017) which states that the elderly have the support of the family. Based on the studies that have been conducted, most cadres have moderate activity level and the rest have a high activity level. Research conducted by Lestari et al (2011) shows that there is a relationship between cadre services and elderly visits to elderly Posyandus. Interventions need to be made to maximize the activeness of cadres so that elderly visits to posyandu elderly can be increased. The results of the study of 19 elderly respondents showed that as many as $79 \%$ of the elderly considered access to posyandu not easy. This is not in line with 
research by Melita and Nadjib (2017) which states that as many as $70,7 \%$ of elderly respondents have easy access. Lack of access to posyandu in the Bedewang area due to the number of posyandu that is not proportional to the area. ${ }^{7,9}$

In this study, all cadres stated that they had met the target of coverage of new elderly in the elderly Posyandu and the target of coverage of elderly screening. This is not following PKP 2018 data from Songgon Health Center which shows the gap between the target and the coverage of new elderly in posyandu and screening of the elderly. The difference shows that the cadres do not know the objectives of coverage that have not yet been reached. The results of research on the knowledge of 4 cadres about posyandu showed that 3 people had good knowledge and 1 person had moderate knowledge about posyandu.

The results showed that 4 cadres stated that the coverage of new elderly in posyandu and coverage of elderly screens was on target. This study studies the cadre's attitude towards coverage of the number of new elderly in posyandu that is not on target to reach the target of coverage for elderly screening. The cadre's attitude includes proposals to increase the coverage target for the number of new elderly people, solutions that cadres can do to increase coverage of new elderly people in the elderly posyandu, and whether the solution can be implemented at this time. The facility proposed by cadres to increase the coverage of elderly screening is the procurement of tools for checking blood cholesterol and uric acid levels.
For the posyandu activities of the elderly in the working area of the Songgon Health Center are registration, elderly gymnastics, and routine health checks/screening. Elderly exercise is considered quite useful to help improve the quality of life of the elderly. Based on a study conducted on 1013 people aged 55-64 years, showed that the best quality of life was found in the respondents group with the highest intensity of physical activity. ${ }^{10}$ In another study which included 176 elderly ( $>60$ years) showed that the quality of life related to health was highest in the elderly with sufficient and high physical activity, while lower in the elderly group with less physical activity. In the group with less physical activity also found a high prevalence of hypertension and diabetes. ${ }^{11}$ In the Posyandu for the elderly, these elderly people will meet with friends who are their age. In a study involving 44 elderly people suffering from diabetes, it was found that there was an improvement in the quality of life of the elderly after the elderly and their groups received education about diabetes. $^{12}$

Three priority problems cause the low coverage of health services and elderly screening in the work area of the Songgon Health Center, Songgon District, Banyuwangi Regency, namely the lack of awareness of the importance of health screening for the elderly, the lack of cadres and incentives for cadres and the difficulty of elderly people coming to the posyandu that are located far from their homes. The low coverage of health services and elderly screening in the work area of Songgon Health Center, Songgon District, Banyuwangi Regency is caused by several factors, including lack of awareness of the 
importance of health screening for the elderly, Lack of cadres and incentives for cadres, and Difficulties of elderly people coming to Posyandu whose location far from the elderly home. Lack of awareness about the importance of health screening for the elderly affects the number of new and old visits to the elderly Posyandu, where some elderly people are reluctant to come because there are no complaints or because they are busy working. The problem of the lack of cadres and incentives for cadres was complained by a number of workshop participants where it was found that most villages in Songgon Subdistrict only had one posyandu run by approximately 5-7 cadres as well as complaints from one cadre representative about cadres starting to lose motivation to perform tasks at the posyandu for the elderly due to lack of incentives. For the problem of the difficulty of the elderly, coming to the posyandu, which is located far from the elderly home, was complained of by a cadre representative who is also an elderly person. According to cadres who often work in the field and face to face with the elderly, the problem of remote access is often a major problem for the elderly, especially those who do not have the support of their families to bring the elderly to the elderly Posyandu.

In increasing the coverage of new elderly in posyandu, the cadre proposes to give information to the community about posyandu, provide community education about the importance of posyandu, increase the number of posyandu, and add facilities and infrastructure. $\mathrm{K}$ ader proposes to provide information and counseling about screening and the importance of screening the elderly. The solution to increase the coverage of elderly screening that can be done today is the same as the solution that is done to increase the coverage of new elderly people in the elderly posyandu, namely by providing counseling about the importance of the elderly posyandu, visiting elderly homes and calling the elderly to invite elderly screening. Based on previous research, increasing elderly knowledge about posyandu can increase elderly visits to posyandu for elderly (Melita and Nadjib, 2018). Good facilities and access can also increase the number of visits (Lestari et al ., 2011). Both studies support the solutions proposed by the cadres. According to the cadres, the solution that can be done at this time to increase coverage is to provide counseling about the importance of elderly Posyandu, visit elderly homes and call the elderly to invite them to the elderly Posyandu. ${ }^{7,9}$

Community therapy that can be implemented to solve the problem of screening coverage is still low in Songgon District, Banyuwangi Regency. The program includes:

(1) Cadre Training. This cadre training contains activities: (a) Making a KOLASE Card (Healthy Elderly Control) which contains the importance of health screening in the elderly, which also contains tables for filling new elderly people in 9 villages in the work area of Songgon Health Center. The making of this card is expected to increase the coverage of elderly health screening by targeting cadres to search for new elderly people every month which are then recorded on this card and deposited to the person in charge of 
the elderly at the Songgon Health Center. ( b. ) This training activity is carried out in 1 meeting, namely at the first meeting for the socialization of the program, how to use, benefits, objectives, performance indicators and evaluation time from the cards that have been made.

(2) Reporting of new elderly. The reporting of the elderly consists of the following activities: (a) The search for new elderly by the Elderly Cadre The elderly cadre from each village collects information from the community regarding villagers belonging to the elderly category. The cadre then visited the house of the elderly to ensure information from the local residents. If the residents meet the criteria of the elderly, the Cadre can do health screening for the elderly at the place or invite the elderly to come to the elderly Posyandu in the area. If the residents refuse to go to the posyandu and choose to go to the puskesmas, the cadres can simply record the identity of the elderly according to the KOLASE card and provide information to the responsible person of the elderly at the puskesmas to be followed up. (b) Cadres report new elderly findings and get a new card when it is full. (c) Monitoring and evaluation of monthly findings and evaluation of all programs at the meeting during the implementation of the elderly Posyandu.

(3) Extension of the elderly Posyandu by Cadres for the Community. Posyandu Counseling by Cadres for the Community bisiisi activities as follows: (a) Conducting counseling by cadres about the importance of coming to the elderly Posyandu to the community. Cadres will be given media in the form of brochures to conduct counseling in their respective villages. Counseling can be done at least once a month to the local residents where the cadres work. (b) Counseling can be adjusted to the activities of local residents, such as religious events, elderly Posyandu, and toddler Posyandu. (c) Counseling materials that can be delivered, but not limited to: About the importance of coming to the posyandu for the elderly and benefits obtained from the elderly posyandu, such as screening for elderly health, free medical treatment, elderly gymnastics, and adding many friends.

\section{CONCLUSION}

Based on the results of the study, all cadres stated that the solution that cadres could do to increase the coverage of new elderly people in the elderly Posyandu and screening the elderly was to provide information to the community about Posyandu, provide community education about the importance of Posyandu, increase the number of Posyandu, and add facilities and infrastructure.

\section{ACKNOWLEDGMENT}




\section{REFERENCES}

1. Depkes RI. 2003. Pedoman Pengelolaan Kesehatan di Kelompok Usia Lanjut. Jakarta: Depkes RI.

2. Depkes RI. 2000. Pedoman Pembinaan Kesehatan Usia Lanjut Bagi Petugas Kesehatan I Kebijaksanaan Program.

3. Kemenkes RI. 2019. Peraturan Menteri Kesehatan Republik Indonesia Nomor 4 Tahun 2019 Tentang Standar Teknis Pemenuhan Mutu Pelayanan Dasar Pada Standar Pelayanan Minimal Bidang Kesehatan. [online]. Available at: http://hukor.kemkes.go.id/uploads/pr oduk_hukum/PMK_No_4_Th_201 9 ttg_Standar_Teknis Pelayanan D asar_Pada_Standar_Pelayanan_Mini mal_Bidang_Kesehatan.pdf.

[Accessed 14 Mey 2019].

4. Kemenkes RI. 2016. Peraturan Menteri Kesehatan Republik Indonesia nomor 25 Tahun 2016 Tentang Rencana Aksi Nasional Kesehatan Lanjut Usia Tahun 20162019. [online]. Available at: http://kesga.kemkes.go.id/images/pe doman/PMK\%20No.\%2025\%20ttg \%20RAN\%20Kes.\%20Lanjut\%20U sia\%20Tahun\%202016-2019.pdf. [Accessed 14 Mey 2019].

5. Kemenkes RI. 2014. Situasi dan Analisis Lanjut Usia. InfoDatin Pusat Data dan Informasi Kementerian Kesehatan RI. [online]. Available at: http://www.pusdatin.kemkes.go.id/re sources/download/pusdatin/infodatin /infodatin-lansia.pdf. [Accessed 14 Mey 2019].

6. BPS, 2018. Statistik Penduduk Lanjut Usia 2017. [Online] Available at: https://www.bps.go.id/publication/20 18/04/13/7a130a22aa29cc8219c5d15 3/statistik-penduduk-lanjut-usia2017.html [Accessed 14 Mey 2019].
7. Lestari P, Hadisaputro S, Pranarka K. 2011. Beberapa Faktor Yang Berperan Terhadap Keaktifan Kunjungan Lansia ke Posyandu Studi Kasus di Desa Tamantirto Kecamatan Kasihan Kabupaten Bantul Provinsi DIY. Fakultas Kedokteran Universitas Diponegoro dan Ikatan Dokter Indonesia Wilayah Jawa Tengah. Media Medika Indonesiana Vol. 45 No. 2, 2011, 74-82. [online]. Available at: https://ejournal.undip.ac.id/index.ph $\mathrm{p} / \mathrm{mmi} /$ article/view/3019. [Accessed 14 Mey 2019].

8. Idayani,et al. 2012. Hubungan Antara Pengetahuan dan Sikap Lansia dengan Keaktifan Lansia Terhadap Pemanfaatan Posyandu Lansia di Desa Windan Makamhaji Kartasura. Universitas Muhammadiyah Surakarta. [online]. Available at: http://eprints.ums.ac.id/18383. [Accessed 15 Mey 2019].

9. Melita., Nadjib Mardiati. 2017. Faktor-Faktor yang Berhubungan dengan Kunjungan Lansia ke Posbindu Lansia di Wilayah Kerja Puskesmas Kelurahan Bintara Kota Bekasi Tahun 2017.Jurnal Kebijakan Kesehatan Indonesia vol.7 No.4 Desember 2018, 158-167. [online]. Available at: https://jurnal.ugm.ac.id/jkki/article/v iew/26409. [Accessed 15 Mey 2019].

10. Puciato, D., Borysiuk, Z., \& Rozpara, M. 2017. Quality of life and physical activity in an older working-age population. Clinical interventions in aging, 12, 16271634.

11. Halaweh, H., Willen, C., GrimbyEkman, A., \& Svantesson, U. 2015. Physical Activity and Health-Related Quality of Life Among Community Dwelling Elderly. Journal of clinical medicine research, 7(11), 845-852. 
12. Ghasemi, M., Hosseini, H., \& Sabouhi, F. 2019. Effect of Peer Group Education on the Quality of Life of Elderly Individuals with
Diabetes: A Randomized Clinical Trial. Iranian journal of nursing and midwifery research, 24(1), 44-49. 